\title{
Two Stay Two Stray Strategy on the Students' Reading Comprehension: The Effectiveness and the Students' Perceptions
}

\author{
Haryati Haryati ${ }^{1}$ \\ Universitas Pamulang, Tangerang Selatan, Indonesia
}

\section{Article History}

Submitted date:

31-07-2021

Accepted date:

03-10-2021

Published date:

21-12-2021

\section{Keywords:}

Two Stay Two Stray, students' perceptions, TSTS, reading comprehension

Abstract

This study was aimed to find out the effectiveness of Two Stay Two Stray (TSTS) strategy on the students' reading comprehension achievement of the first semester students of English department at Universitas Pamulang, and to know the students' perception in applying TSTS. A quantitative approach was applied in this research by using Independent T-test calculation. The writers selected the samples comprising 60 students (30 students in the experimental class and 30 students in the control class) to obtain the data by random sampling. The writers used two kinds of instruments to collect the data: a reading test and a questionnaire. These instruments were administered to answer stated research questions. A reading test was used to find out the effectiveness of TSTS strategy by SPSS calculation, and the questionnaire was distributed to find out the students' perceptions in applying TSTS in the reading activity. The research findings indicated the result of the hypothesis based on MannWhitney $\mathrm{U}$ test the Sig 2 -tailed value $0.019<0.05$, which means that the Null Hypothesis (H0) is rejected and Alternative Hypothesis (Ha) is accepted. Furthermore, students assume that the Two TSTS strategy is more enjoyable than the conventional strategy $(7.7 \%)$, they guess the main ideas of the text on the basis of pictures, charts or figures $(7,4)$, and they understand their reading comprehension text before straying to another group (7.3\%). Therefore, it shows the TSTS strategy shares the beneficial encouragement on the students reading comprehension.
\end{abstract}

\section{Kata Kunci:}

Two Stay Two Stray, persepsi mahasiswa, TSTS, pemahaman membaca

\section{Abstrak}

Penggunaan Strategi Two Stay Two Stray pada Pemahaman Membaca Siswa: Efektifitas dan Persepsi Siswa

Penelitian ini bertujuan untuk mengetahui keefektifan penggunaan strategi Two Stay Two Stray (TSTS) terhadap pemahaman membaca siswa semester I fakultas Sastra Universitas Pamulang, dan untuk mengetahui perspektif siswa dalam menerapkan TSTS. Pendekatan kuantitatif dilakukan dalam penelitian ini dengan menerapkan perhitungan independent T-Test. Untuk memperoleh data, penulis memilih sampel yang terdiri dari 60 siswa (30 siswa di kelas eksperimen dan 30 siswa di kelas kontrol) dengan cara random sampling. Untuk mengumpulkan data, penulis menggunakan dua jenis instrumen: tes membaca dan angket. Instrumen ini diberikan untuk menjawab pertanyaan penelitian. Tes membaca digunakan untuk mengetahui keefektifan strategi TSTS dengan aplikasi SPSS, dan angket dibagikan untuk mengetahui persepsi siswa tentang penerapan TSTS dalam kegiatan membaca. Hasil penelitian menunjukkan hasil hipotesis berdasarkan uji Mann-Whitney U nilai Sig 2-tailed 0,019 < 0,05 yang berarti Hipotesis Null (HO) ditolak dan Hipotesis Alternatif (Ha) diterima. Selanjutnya siswa beranggapan bahwa strategi TSTS lebih menyenangkan dari pembelajaran biasa $(7,7 \%)$, mereka menebak gagasan utama teks berdasarkan gambar, bagan atau gambar $(7,4)$, dan mereka memahami teks pemahaman bacaan saya sebelum menyimpang ke kelompok lain (7,3\%). Hasil ini menunjukkan bahwa strategi TSTS memberikan pengaruh positif yang bermanfaat pada pemahaman membaca siswa.

\footnotetext{
Corresponding author:

${ }^{1}$ haryati.safa@gmail.com
} 


\section{Introduction}

Reading is an essential skill that helps students to be able to understand materials or articles in language learning. Miller and Moss (2013) state that reading is an essential practice. It involves the comprehension process depending on the readers' characteristics and language process. Discussing the comprehension level frequently merges into a discussion of a reader's ability to understand at a certain level. Similarly, Grellet (2010, p.3) states, "reading comprehension is an understanding a written text means extracting the required information from is as effective as possible." Therefore, it is beneficial for the students to develop background knowledge, improve fluency and comprehension, to heighten motivation, to increase reading achievement, and toimprove fluency and comprehension, to heighten motivation, increase reading achievement, and improve fluency and comprehension, heighten motivation, increase reading achievement, and to help students raise their vocabulary. It is also crucial for the students to enrich the vocabulary and knowledge related to their lives; motivation can also be one internal factor to enhance the students' reading comprehension (Ahmadi, 2017). When they have great encouragement to read, they will be able to elevate their reading skill. Hence, reading is an activity to get meaning from words or symbols, and how this ability is used to recognize, understand and interpret the words. Talking about the importance of reading skills, the students also need to improve it to pass the TOEFL, IELTS, or TOEIC. Those tests assess reading comprehension.

Furthermore, the purpose of reading is to help the students to get the information. The process of reading also involves identifying and leading words to develop students' comprehension (Iwuk, 2007) Reading is about understanding written texts on complex activities involving identification, information acquisition, and comprehension improvement. In addition, reading skill is one of the main skills in university or schools that the educators need to familiarize the students. Unfortunately, not every student can acquire reading skills at the same rate since they present their distinctive learning styles. According to the writers' preliminary observation, most of the students face difficulties in the reading process: the students have low comprehension in reading a text, and they have problems in understanding each word of sentences, poor vocabulary, and are unable to comprehend the reading text. The other difficulties that can be found among the students are the existence of various meanings within the same word, such as words that deliver more than one meaning. For example, the word "righte can mean approval and direction side, which is the opposite of left, and the word "present" means a gift and the act of existing. The last the students do not apply a particular strategy in reading comprehension. Oakhill et al. (2015) also summarize that students face several obstacles to comprehending the reading context: vocabulary, main ideas, and content comprehension.

Generally, to minimize the students' problems or difficulties in reading comprehension, the teacher needs to seek a solution to overcome or assist students' problems. Therefore, the teacher needs to explore their knowledge about several strategies in teaching reading and introduce them to the students to assist them in comprehending the reading material. Some researchers have promoted some reading strategies such as Metacognitive, Cognitive, Two Stay Two Stray, and others. The two Stay Two stray reading strategy is also effective using the Two Stay Two Stray strategy. The two Stay Two Stray strategy is one of the cooperative learning models developed by Spencer Kagan in 1994. Two students will be the guests (stray) in a group, and two will welcome other groups (stay). Specifically, the teacher divides the students into several groups, each group consisting of four students. The group formed should also be heterogeneous; each group has one high-ability student, two medium-ability students, and one low-ability student to offer passive and low-ability students opportunities to learn from others. Then, the teacher distributes sub-topics to each group to be discussed with the members of each group. Having finished discussing, two students from each group leave their group to visit another group as guests, and two remaining students in the group share their understanding and information with guests from other groups. Moreover, students as guest should 
return to their own groups to inform their understandings from other groups. The discussion to obtain the final results is carried out, and in the final process, each group performs the results of their work (Huda, 2013). This alternative method is involved in solving the students' problems with organized them into an equal group. According to Cohen, et al. (2004), applying Two Stay Two Stray can enhance students' comprehension about themselves and many things occurring in the word, and it provides an opportunity for them to share their new viewpoint with others. This strategy is able to be cooperative activities in gaining a comprehension of one particular topic, and its utilization leads them to be more vigorous in discussion participation, question and answer, and explanation elaboration.

The benefit of the strategy is also helping the students with special needs. The student having a problem with reading comprehension text can assist other students in learning reading comprehension in the students' group situation. Apriliawati (2017) claims that the students are enthusiastic and interested in learning reading comprehension by using Two Stay Two Stray techniques because they can share with their group. The benefit of Two Stay Two Stray is also supported by Sulisworo and Suryani (2014) who highlight that by using Two Stay Two Stray' structure, students will get used to appreciate others' arguments, to convey their opinions to others, and to enhance their self-reliance in expressing ideas. In addition to the special needs, it allows the students to promote discussion both individually and in groups for reviewing and understanding subject matters in the reading comprehension text. In implementing the Two Stay Two Stray strategy in students' reading comprehension, the teachers can implement several important procedures in the learning process: dividing the students into several groups, distributing the topic, presenting the discussion result, noting the ideas from other groups, and presenting their comprehension to all groups. At the end process, teachers will question the students to dig the students' comprehension.

Apriakanti, Kusuma, and Nurhayati (2020) investigate the implementation of TSTS on the students' reading skills. They assumed that TSTS shares positive effects on the students' reading achievement. The students can elevate their critical thinking and comprehension when they apply TSTS strategy. Sari (2019) also applied the use of TSTS on the students' reading comprehension. She found that TSTS produces cooperative learning environments among the students, the students perform better comprehension in gaining the meaning, and the students show the encouraging responses of applying TSTS in their reading process. The teacher creates a different situation in the class to deliver material that relates to reading comprehension. It relates to how the teacher teaches and delivers the material in the class. The interesting learning will make the students more enthusiastic in learning. Cooperative learning or grouping class is the teachers' way to make the students more interactive and talkative and create that atmosphere. Teachers can apply the Two Stat Two Stray strategy as one of the learning models in cooperative learning. Furthermore, Saputra (2016) claims that TSTS is an effective strategy to enhance the students' reading comprehension. The students obtain positive motivation in reading activities like self-confidence, social interaction among students and cooperative learning. They also get better comprehension during reading process.

This research focuses on finding out the effectiveness of TSTS strategy on the students' reading comprehension and the students' perception of applying the strategy in the reading activities. The research questions are two folds: "Are there any significant effects of the Two Stay Two Stray reading strategy on students' reading comprehension? and "What are the students' perceptions of applying the Two Stay Two Stray on their reading comprehension?" Furthermore, one of the novelties of this research is the TSTS strategy can be applied in the online learning environment in a pandemic situation. Therefore, it assists teachers in creating interaction among students through online applications, whereas the current condition limits the students to have cooperative learning activities. Moreover, previous studies conducted by Kadiriandi \& Ruyadi (2017) and Ainain, Dahnilsyah, \& Syarfi (2019) focused on TSTS implementation in the classroom activities; however, the present study focuses on the implementation of TSTS through online platforms. It considerably delivers a 
distinctive atmosphere. Therefore, further research is needed to determine whether TSTS as a cooperative activity can be conducted in various conditions.

\section{Methods}

The writers used the quantitative approach to determine the effectiveness of the Two Stay Two Stray strategy on the reading comprehension skills of the first students in the English department of Universitas Pamulang. The processes were started from stating problematic statements, making the research questions, reviewing the relevant literature, and analyzing the data through numerical data. Similarly, a quantitative method can be defined as a research method used to focus on a particular sample, data collection, the instruments of research, and statistical data analysis (Sugiyono, 2010).

\subsection{Data Source}

The data were taken from the first-semester students of English department. The population is 125 students in morning classes. From this population, the writers selected two classes (60 students) to be the sample in this research by having simple random sampling. It is a way to take samples from the population carried out randomly without considering students' grades/ grades in one population. One class consisted of 30 students who were in the experimental class, and 30 students who were in the control class.

\subsection{Instruments}

In this research, the writer used two kinds of instruments: reading comprehension test and questionnaires. The reading comprehension test consists of 50 questions, including several elements of reading comprehension: main idea, vocabulary, specific information, reference, and inference. This test was administered to find out the effectiveness of TSTS strategy in the students' reading comprehension. Furthermore, the writer also distributed the questionnaires to know the students' perception of the TSTS strategy in the reading process.

\subsection{Data Collection}

To collect the data, the writers began to do pre-observation to identify the students' reading comprehension problems. After that, the writers determined the Two Stay Two Stray strategy as the teaching reading comprehension strategy appropriates the students' problems. The writers then prepared the instruments for the research, such as the reading comprehension test and questionnaires. Then, the writer tried to give the students a reading comprehension test as the pre-test. Next, the writer started the treatment, which begins to habituate the students learning the reading comprehension using the Two Stay Two Stray strategy. The process was conducted for seven meetings including the test. Finally, the writers administered a post-test to the students to gain the data. After giving the test, the writers distributed the questionnaire to find out the students' perceptions after applying the TSTS strategy.

\subsection{Data Analysis}

The writers analyzed the data to test the effectiveness of the Two Stay Two Stray strategy on the students reading comprehension by using SPSS to check its validity, reliability, normality, hypothesis and applied the Independent T-test. The last, the results of the data analysis were interpreted. The findings showed whether the hypothesis of using the Two Stay Two Stray was significant or not. Afterward, the writers also recorded the students' perception of the TSTS strategy in the form of percentages and explained the results.

\subsection{Statistical Hypotheses}

Before determining the result of the hypotheses, the writers proposed two hypotheses to test: a. H0: there is empirical evidence that the use of the Two Stay Two Stray strategy is not effective in teaching reading comprehension in the first students semester in the English department of Universitas Pamulang 
b. Ha: there is empirical evidence that the use of the Two Stay Two Stray strategy is effective in teaching reading comprehension in the first students semester in the English department of Universitas Pamulang

\section{Results and Discussion}

\subsection{Data Normality Test of Post-Test}

Table 1: Data Normality of the Post-test

\begin{tabular}{lllll}
\hline Post-test & Class & \multicolumn{3}{c}{ Kolmogorov-Smirnov $^{\mathbf{a}}$} \\
\cline { 2 - 5 } & Statistic & $\mathrm{df}$ & Sig. \\
\cline { 2 - 5 } & Experiment Class & .172 & 30 & .023 \\
& Control Class & .273 & 30 & .000 \\
\hline
\end{tabular}

The result of the normality test from the post-test indicates that the experimental class is normally distributed. The significance result (Sig.) of the experimental class was 0.023 , which means that it is greater than $\alpha$ (Sig.) $0.023>0.05$, then $\mathrm{H} 0$ is accepted, and the data were normally distributed. While from the control class, the result of the is equal to (Sig.) $0,000<0.05$, which means the (Sig.) is smaller than $\alpha$, then $\mathrm{HO}$ is rejected. It states that the data is not normally distributed. Based on these data, the analysis test proceeds to the hypothesis test using the Mann-Whitney test.

\subsection{Data Hypothesis Test of Post-Test}

The hypothesis testing of post-test is used to conclude the result from a hypothesis which performed on the sample data from a larger population. It aims to measure and examine the samples being analyzed. The hypothesis test of post-test conducted in this study using the non-parametric Mann-Whitney test

Table 2: Data Hypothesis Test of Post-Test

\begin{tabular}{lr} 
& Post-test \\
\hline Mann-Whitney U & 293.000 \\
\hline Wilcoxon W & 758.000 \\
\hline Z & -2.339 \\
\hline Asymp. Sig. (2-tailed) & .019 \\
\hline a. Grouping Variable: class & \\
\hline
\end{tabular}

The hypothesis test of the post-test above indicates that $\mathrm{H} 0$ is rejected. This is based on the calculation is if the Sig 2 -tailed value $<0.05$, then $\mathrm{H} 0$ is rejected. The calculation results show a pvalue is about 0.019 , which means less than 0.05 . So, $\mathrm{H} 0$ is rejected, and $\mathrm{Ha}$ is accepted. This figure shows that the Two Stay Two Stray strategy is effective in teaching reading comprehension. 


\subsection{Data Statistic of Post-Test}

Table 3: Data Statistic of Post-Test

\begin{tabular}{llrrrr}
\hline \multicolumn{1}{c}{ class } & N & \multicolumn{1}{c}{ Mean } & Std. Deviation & Std. Error Mean \\
\hline posttest & 1 (Experiment Class) & 30 & 82.13 & 4.890 & .893 \\
& 2 (Control Class) & 30 & 79.27 & 4.842 & .884 \\
\hline
\end{tabular}

The result above shows that class 1 (experimental class) has 30 students, and the mean score is 82.13. Meanwhile, class 2 (control class) also has 30 students, and the mean score is 79.27. It can be concluded that the preliminary finding in the experiment class has a higher mean score than the control class.

\subsection{The Two Stay Two Stray Effect}

Table 4: Two Stay Two Stray Effect

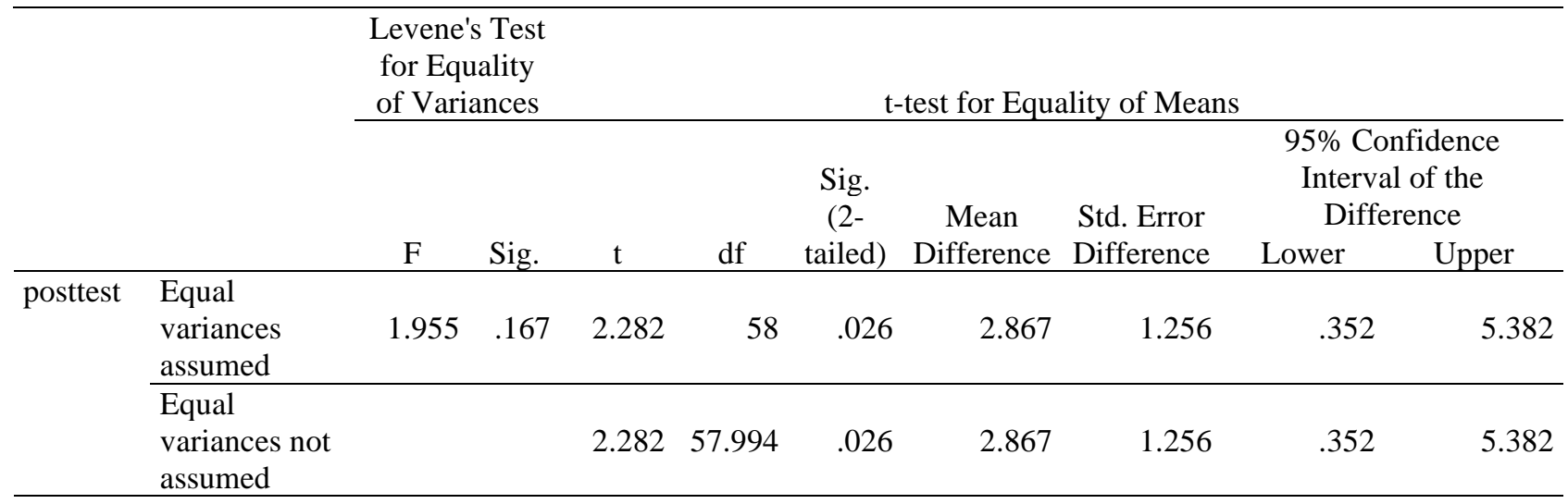

After analyzing the statistic test, the writers analyzed the effect of Two Stay Two Stray on the students' reading comprehension. To analyze the effect, the writer checked the score of sig. 2-tailed. In the table above, it is clear that the sig 2-tailed is 0.026 which means, Ha is accepted and $\mathrm{H} 0$ is rejected. Based on the hypothesis stated in chapter 3, Ha is accepted if the score of sig. 2-tailed is lower than 0.05. However, $\mathrm{H} 0$ is accepted if the sig. 2-tailed is higher than 0.05. As a result, the above table showed that the sig. 2-tailed is 0.026 , and it is lower than 0.05. It can be assumed that the Two Stay Two Stray strategy has a significant effect on the students' reading comprehension.

The Two Stay Two Stray strategy is significant in learning reading comprehension compared to the conventional strategy. The effectiveness of the Two Stay Two Stray strategy can be seen from the experimental class, which presents more active involvement in the learning process and comprehending the strategy to solve their problem, such as understanding a whole reading material in a short time in learning reading comprehension. In this situation, the students also shared their experiences and knowledge with other groups and friends about the reading material. In the learning process, the experimental class's average gained score is 0.531 , whereas the average gained score of the control class is 0.478 . The success of the Two Stay Two Stray strategy in reading comprehension is evidenced by the writers and the other researchers who were doing this research. Arthy and Nagaraj (2012) sum up that Two Stay Two Stray is effective in learning reading comprehension since this strategy allows students to share their viewpoints, arguments, and information with other groups. This argument is also supported by Mulya \& Yetti (2019) which point out that the Two Stay Two Stray strategy emphasizes the interaction between students, in which every member of the group has an equal responsibility to share their comprehension with the other group. Similarly, Suliworo \& Suryani (2014) sum up that the strategy produces positive, cooperative learning activities, motivation, and reading achievement. In brief, most previous researchers investigated the strategy and found similar positive findings on the students' reading comprehension and achievement. 


\subsection{The Data Questionnaires}

Table 5: Students' Reading Comprehension Questionnaire

\begin{tabular}{lll}
\hline No. & \multicolumn{1}{c}{ Questions } & Percentage \\
\hline 1. & $\begin{array}{l}\text { I understand the main topic/idea of the reading comprehension text easily when } \\
\text { using TSTS }\end{array}$ & $6.6 \%$ \\
\hline 2. & $\begin{array}{l}\text { I look into dictionaries when finding a new/difficult word in the reading } \\
\text { comprehension text. }\end{array}$ & $5.6 \%$ \\
\hline 3. & I conclude the main idea of the whole passage from its title or subtitles. & $7.1 \%$ \\
\hline 4. & I do not focus on obtaining the implied meaning of the reading comprehension text. & $6.0 \%$ \\
\hline 5. & When I read the reading comprehension text, I leave out the new words & $5.3 \%$ \\
\hline 6. & $\begin{array}{l}\text { While reading a text, I stop reading to find out the structural sentences found in the } \\
\text { text. }\end{array}$ & $5.4 \%$ \\
\hline 7. & I guess the main ideas of the text from pictures, charts or figures in the passage & $7.4 \%$ \\
\hline 8. & $\begin{array}{l}\text { I discuss with the member of my group about the complicated sentences in the text } \\
\text { of reading comprehension. }\end{array}$ & $7.3 \%$ \\
\hline 9. & $\begin{array}{l}\text { My friends and I read the reading comprehension and discuss the assignment } \\
\text { together. }\end{array}$ & $5.8 \%$ \\
\hline 10. & I guess the meanings of new words in context when reading & $7.1 \%$ \\
\hline 11. & $\begin{array}{l}\text { I try to describe the main idea of the reading comprehension to the member of } \\
\text { another group which strayed to my group. }\end{array}$ & $6.4 \%$ \\
\hline 12. & The group which strayed is clearly explained their text of reading comprehension. \\
\hline 13. & I try to understand my reading comprehension text before straying to another group. & $7.2 \%$ \\
\hline 14. & $\begin{array}{l}\text { Learning reading comprehension by grouping makes the process of reading clear } \\
\text { and quick. }\end{array}$ & $7.0 \%$ \\
\hline 15. & Two Stay Two Stray (TSTS) strategy is more enjoyable than the previous strategy. & $7.7 \%$ \\
\hline & & $7.7 \%$ \\
\hline
\end{tabular}

The above questionnaire was distributed to the students after they had applied the TSTS reading strategy. Briefly, the students did not have any experience in applying the TSTS strategy in the previous learning activity, and in the study, the students were introduced and trained to apply TSTS strategy in the reading classroom. The questionnaire is used to strengthen the findings of TSTS effect on the students' reading comprehension and to find out the students' perception. The table above shows the students' perception of applying the TSTS strategy in their reading process. The percentage results were stemmed from the total numbers of students' responses for each question item, and the number is converted into a percentage. From the 15 questions, the writers highlight eight questions having high percentages (7.0\% to $7.7 \%)$ : TSTS is an enjoyable strategy to learn; they gain the ideas from pictures, they can comprehend the ideas before straying others; they are able to describe the main ideas to other groups; they enjoy discussing with others, grouping activity makes them gain comprehension rapidly. The students' perceptions show that the Two Stay Two Stray strategy positively encourages the students in their reading comprehension. The perceptions also indicate the students' abilities in reading comprehension. For instance, the students can predict the main idea and get the information in reading comprehension through the title or image of the text. In this case, the students habituate to do not focus on searching the meaning of words in the dictionary. Then, the students' cooperation in solving complex reading comprehension by sharing roles within the group and expressing their opinions about what they know or get in the reading comprehension text to their own group and other groups. Moreover, the students enjoy their learning process in class, it makes them get a good result on their post-test. Those points strongly show the evidence that the Two Stay Two Stray strategy effectively improves the students' reading comprehension.

\subsection{Discussion}

Briefly, using the TSTS reading strategy leads to a positive effect on the students' reading comprehension. The students' score significantly improves. The finding of this research was also 
consistent with the previous study conducted by Sukmayati (2014). She claimed that TSTS is an effective strategy to enhance students' reading comprehension; they achieve their comprehension. It is in line with Ainain Dahnilsyah and Syarfi (2019), who found that TSTS positively affects the students' reading, like having better comprehension and collaborating with others.

Moreover, the study reveals that the students actively communicate with other students; hence, they can gain the main ideas rapidly and become more active in delivering their thoughts. Kadiriandi \& Ruyadi (2019) share similar findings that the strategy encourages students to be active participants in the discussion process. Although TSTS affects the students' reading comprehension, they face problems understanding the difficult word stated in the text (5.6\%), ignoring those words. Qiann (1999) assumes that reading compression has a close relation to vocabulary mastery. Students need to achieve 3000 words to conquer the ideas in a text. It can be interpreted that the students have positive results and perceptions in using TSTS while reading. Hence, it can be an appropriate strategy to promote the students' reading performance.

\section{Conclusion}

From this study, the writers assume that Two Stay Two Stray reading strategy is one of the cooperative learning activities that assist the students to elevate their reading comprehension up; it also constructs the students' intellectual capabilities to share understanding with their friends and take the responsibility of their group. Furthermore, the TSTS strategy positively affects the students' reading performance to achieve better results. The students also respond to their perception in applying the TSTS strategy while reading encouragingly; they supportively enjoy the learning, determine the topic, comprehend and describe the ideas.

\section{References}

Ahmadi, M. R. (2017). The Impact of Motivation on Reading Comprehension. International Journal of Research in English Education, 2(1), 1-7.

Ainain, N., Dahnilsyah, Syarfi, M. (2019). The effect of two stay two stray strategy on reading comprehension ability of the second year students of SMAN 1 Kandis. JOM FKIP 6 (1). https://jom.unri.ac.id/index.php/JOMFKIP/article/view/23890

Apriakanti, D., Kusuma, M., \& Nurhayati, M. (2020). The Effectiveness of Two Stay Two Stray (TSTS) Cooperative Learning Model in Improving Students' Critical Thinking Skills. Journal of Science Education Research, 4(1). https://doi.org/10.21831/jser.v4i1.34240

Apriliawati, D., et al. (2017). The Effect of Two Stay Two Stray (TSTS) Method on Recount Text Writing at the Eighth Grade Students of Smpn 2 Sawahan. English Teaching Journal, 5(2). http://doi.org/10.25273/etj.v5i2.5445

Arthy, V. (2012). Enhancing Reading Comprehension Skill Through Small Group Interaction Technique: A Comparative Study. International Journal of scientific Research, Vol, 1, NO. 5 https://10.36106/IJSR

Cohen, E.G., et al. (2004). Teaching Cooperative Learning. State University of New York Press

Huda, M. (2013). Model Pengajaran dan Pembelajaran. Yogyakarta: Pustaka Belajar.

Iwuk, P. (2007). A Guide for Reading Comprehension. PT. Citra Aji Group. 
Kadiriandi, R., \& Ruyadi, Y. (2017). Pengaruh penerapan model pembelajaran model Two Stay Two Stray (TSTS) terhadap peningkatan keaktifan dan hasil belajar sosiologidi sma Pasundan 3 Bandung. SOSIETAS, 7 (2), p.429. DOI: https://doi.org/10.17509/sosietas.v7i2.10362

Miller, D \& Moss, B. (2013). No More Independent Reading Without Support: Heinemann Publishing

Mulya, T. \& Yetti, Z. (2019). Using two stay two stray technique in teaching reading comprehension at junior high school. English Language Journal, 8(1). https://doi.org/10.24036/jelt.v8i1.103347

Oakhill, J, et al. (2015). Understanding And Teaching Reading Comprehension. Routledge

Qian, D. 1999. Investigating the relationship between vocabulary knowledge in reading comprehension. Canadian modern language review. 56 (2), 238-308. http://dx.doi.org/10.3138/cmlr.56.2.282

Sari, D. F., et al. (2019). The Strategy of Two Stay Two Stray to Improve EFL Students' Reading Skill. Studies in English Language and Education Journal, 6(1). https://doi.org/10.24815/siele.v6i1.13057

Saputra, A. (2016). Use of Two Stay Two Stray Strategy in Teaching Reading. English Education Journal, 7(2), 219-232.

Sugiyono. (2010). Metode Penelitian Pendidikan Pendekatan Kuantitatif, Kualitatif, dan R\&D. Alfabeta.

Sukmayati, S. (2014). Applying two stay - two stray strategy to improve student's reading comprehension. Getsempena English Education Journal 1 (1). DOI: https://doi.org/10.46244/geej.v1i1.667

Sulisworo, D \& Suryani, F. (2014). The Effect of Cooperative Learning, Motivation and Information Technology Literacy to Achievement. International Journal of Learning and Development, 4(2). https://doi.org/10.5296/ijld.v4i2.4908 